\title{
Odspojenie katodowe powłoki jako zjawisko mogące naruszyć integralność gazociągu
}

\begin{abstract}
W artykule omówiono zjawisko odspojenia katodowego powłoki izolacyjnej nałożonej na konstrukcję stalowego gazociągu. Dokonano przeglądu badań laboratoryjnych tego zjawiska wykonywanych na powłokach izolacyjnych stosowanych w polskim przemyśle. Przedstawiono szczegółowo czynniki, które mogą mieć wpływ na szybkość korozji na badanej powierzchni rurociągu.
\end{abstract}

Słowa kluczowe: odspojenie katodowe, potencjał, stanowisko badawcze, badania terenowe, badania laboratoryjne, szybkość korozji.

\section{Cathodic disbonding coating as a phenomenon that could compromise the integrity the pipeline \\ The article discusses the phenomenon of cathodic disbonding insulating coating applied to the design of the steel pipeline. Laboratory research of this phenomenon was carried out on insulating coatings used in the Polish industry. The factors that can influence the rate of corrosion on the test surface of the pipeline are described in detail.}

Key words: cathodic disbonding, potential, the position of research, field tests, laboratory tests, the rate of corrosion.

\section{Wstęp}

Naruszenie integralności czynnego gazociągu może spowodować poważną w skutkach awarię. Jednym z czynników mogących przyczynić się do powstania awarii jest zjawisko odspojenia katodowego powłoki izolacyjnej, które występuje w miejscach jej nieszczelności, tj. w defektach powłoki.
Dotychczas badania zjawiska odspojenia katodowego były prowadzone w laboratoriach zgodnie $\mathrm{z}$ normą obowiązującą dla danego rodzaju powłoki izolacyjnej. Tymczasem najczęściej z powłoką izolacyjną współpracuje ochrona katodowa, która w określonych warunkach może przyczynić się do zwiększenia szybkości korozji rurociągu.

\section{Zjawisko odspojenia katodowego powłoki}

Na gazociągach stalowych nałożone są powłoki mające za zadanie odizolować powierzchnię stalową gazociągu od elektrolitu glebowego, w którym gazociąg jest ułożony. Jednakże sama powłoka nie wystarczy, aby zapewnić ochronę przed korozją. Uzupełnieniem tego rodzaju biernej ochrony rurociągu jest ochrona czynna w postaci ochrony katodowej. Ochrona katodowa zabezpiecza gazociąg przed korozją, która mogłaby się pojawić w wyniku uszkodzenia powłoki izolacyjnej podczas jego eksploatacji. Właściwa eksploatacja powinna zapewnić integralność gazociągu. Pod pojęciem integralności gazociągu rozumie się taki jego stan techniczny, który pozwala na bezpieczny i ciągły przesył gazu [3]. Starzejące się gazociągi stwarzają potencjalne ryzyko awarii, które nie może być całkowicie wyeliminowane [2].

W systemach ochrony katodowej prąd przepływający przez metal może spowodować uwolnienie atomów wodoru, doprowadzając do odspojenia powłoki. Prąd ten przepływa tylko przez metal w miejscu uszkodzenia powłoki izolacyjnej, a ilość przepływającego prądu jest zależna od wielkości defektu. Jeżeli wielkość uszkodzenia powłoki izolacyjnej wzrasta, zwiększa się ilość prądu przepływającego przez metal w wyniku spadku napięcia na granicy faz 
powłoka-powierzchnia metalu, co powoduje odrywanie powłoki od metalu. Jeśli nie ma defektu powłoki izolacyjnej, zjawisko odspojenia katodowego powłoki nie występuje (rys. 1).

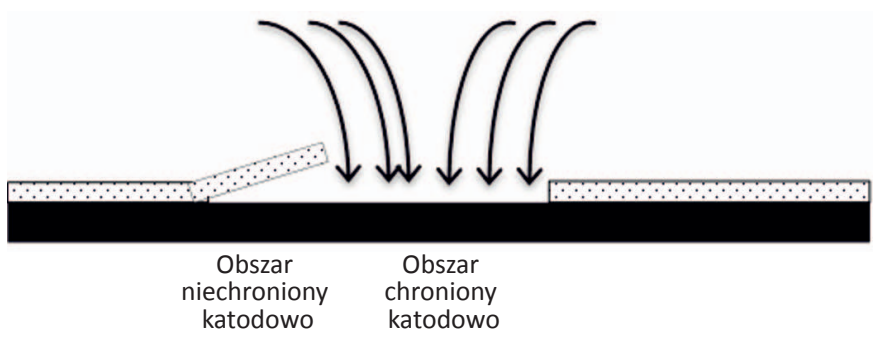

Rys. 1. Zjawisko odspojenia powłoki pod wpływem katodowej polaryzacji stali

Odspojenie katodowe jest to utrata przyczepności pomiędzy powłoką i jej metalowym podłożem pod wpływem produktów reakcji katodowej redukcji, które pojawiają się na powierzchni defektu powłoki [1]. Systemy ochrony katodowej instalowane są, aby zapobiec korozji powierzchni metalu lub ją spowolnić. Odspojenie powłoki występuje, gdy system ochrony katodowej oddziałuje chemicznie lub fizycznie na powłokę, co ostatecznie może spowodować korozję pod powłoką izolacyjną w miejscu defektu. Na skutek nadmiernego oddziaływania prądu elektrycznego ochrony katodowej mogą zmieniać się dynamicznie warunki chemiczne i fizyczne i negatywnie wpływać na powłokę w bezpośrednim sąsiedztwie defektu. Szczególnie niekorzystna sytuacja występuje, gdy nadmiernie nakładają się różne potencjały katodowe pochodzące z różnych źródeł (np. prądy błądzące). Występuje wtedy reakcja redukcji tlenu w porach powłoki i rozpoczyna się akumulacja jonów sodowych poprzez ich transport przez przewodzące ścieżki w wyniku działania $\mathrm{NaOH}$ na pory powstałe w powłoce. Alkalizacja jest główną przyczyną katodowego odspojenia powłoki, która odbywa się zarówno poprzez hydrolizę jonów sodu $(\mathrm{Na})$ na granicy faz wiązania, które łączą się z powłoką na powierzchni rury w wyniku bezpośredniego odspojenia albo poprzez hydrolizę z samą powłoką w wyniku depolimeryzacji. Powstałe pęcherzyki zawierają roztwór zasadowy ( $\mathrm{pH}$ do $13 \div 14$ ), który zapobiega korozji i pasywuje powierzchnię stali w defekcie. Gdy pęcherzyki pękają, pod defektem na stali chronionej katodowo wytwarzają się osady wapienne w tym obszarze.

Na granicy powłoka-powierzchnia stali w defekcie dochodzi do powolnego odrywania się powłoki od stali. Ten proces w zależności od jakości powłoki, siły adhezji materiałów powłokowych i prawidłowego przygotowania powierzchni stali może mieć różną szybkość. Coraz większa powierzchnia defektu powstająca w wyniku pękania pęche- rzy - może doprowadzić do wzrostu poboru prądu ochrony katodowej [5]. Na skutek oddziaływania prądu ochrony katodowej w defekcie powłoki izolacyjnej powstają osady, które pokrywają powierzchnię defektu, coraz bardziej powiększając swoją powierzchnię i wnikając pod powłokę. W wyniku oddziaływania prądu ochrony katodowej na defekt następuje zmiana właściwości elektrolitu, który staje się coraz mniej natleniony, a jego odczyn - coraz bardziej zasadowy. Oba te czynniki zmniejszają szybkość korozji stali, tworząc tlenki na coraz to bardziej pordzewiałej powierzchni defektu. Niestety ta sytuacja może nie występować we wszystkich defektach powłoki izolacyjnej mimo oddziaływania prądu ochrony katodowej na defekty. Zmniejszenie natlenienia i alkalizacja elektrolitu moga nie występować w wystarczającym stopniu, aby zahamować proces odspojenia.

Chemiczne zmiany wpływające na potencjał wcześniej utlenionych powierzchni występują wolniej niż na czystej powierzchni stali. Dzieje się tak ze względu na porowatość powłoki, która działa jak bariera spowalniająca rozprzestrzenianie i ruch substancji jonowych. Jeżeli natleniony elektrolit będzie stale dopływał w rejon defektu i pod powłokę izolacyjną, szybkość korozji się zwiększy i może stać się niekontrolowana, równocześnie będzie trwał proces odspajania powłoki od powierzchni stali. Odspojenie katodowe powłoki izolacyjnej może być kontynuowane poprzez: ciągłą modyfikację chemiczną elektrolitu w rejonie defektu powłoki, zwiększanie w rejonie defektu zasadowości w wyniku oddziaływania ochrony katodowej oraz dalsze przyrosty produktów korozji w miejscu defektu powłok.

Zjawisko odspojenia katodowego powłoki izolacyjnej może być bardzo niebezpieczne. $Z$ powodu złego wykonania powłoki jej przyczepność do podłoża może być bardzo obniżona w miejscu defektu. Powłoka izolacyjna może się łatwo odspoić. W późniejszym czasie elektrolit glebowy wypełniający przestrzeń między odspojoną powłoką a powierzchnią chronionej konstrukcji stanie się źródłem korozji. Prąd ochrony katodowej będzie chronić powierzchnię bezpośrednio eksponowaną, a nie dotrze pod odspojoną powłokę izolacyjną i nie będzie jej chronił katodowo. Zgodnie z normą PN-EN 12954:2004 szybkość korozji jest na akceptowalnym niskim poziomie, jeśli jest nie większa niż 0,01 mm/rok [5]. Zjawisko odspojenia katodowego może utrudnić spełnienie tego kryterium.

Dla powłok o grubości poniżej $200 \mu \mathrm{m}$ zjawisko katodowego odspojenia jest znacznie bardziej niebezpieczne, dlatego zaleca się stosowanie powłok o grubości znacznie powyżej $200 \mu \mathrm{m}$. 


\section{Wybrane czynniki mogące mieć wpływ na szybkość korozji}

Szybkość korozji jest uzależniona od wielu czynników, które osobno, jak i w połączeniu ze sobą mogą decydować o przebiegu procesu korozji na eksponowanej powierzchni stali.

Na szybkość korozji mogą mieć wpływ między innymi: stężenie tlenu, przewodnictwo elektrolitu na powierzchni stali, kwasowość środowiska $(\mathrm{pH})$, temperatura i rodzaj materiału. Czynniki te przedstawiono poniżej.

- Stężenie tlenu: szybkość korozji zależy od stężenia tlenu rozpuszczonego w wodzie i docierającego do powierzchni stali [4].

W niższych stężeniach szybkość korozji rośnie, ale szybko osiąga maksimum. Przy dalszym wzroście stężenia tlenu szybkość korozji spada, z powodu pasywacji powierzchni defektu.

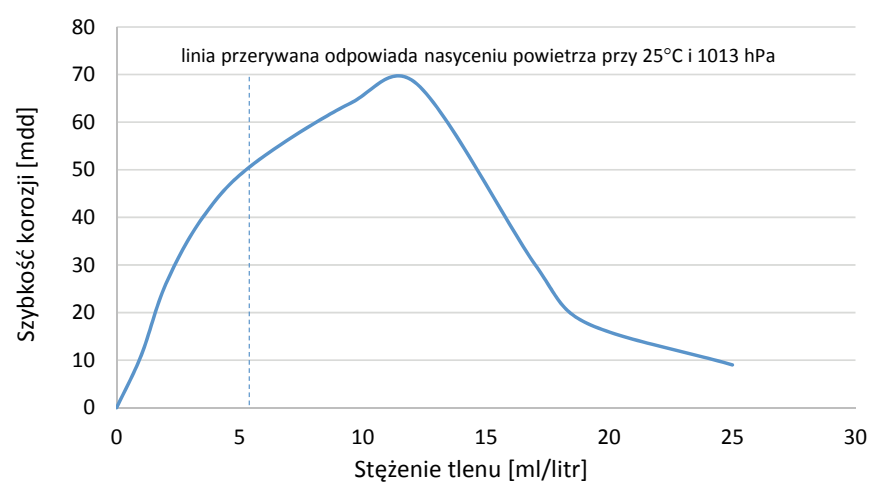

Rys. 2. Wpływ stężenia tlenu na szybkość korozji

- Przewodnictwo elektrolitu na powierzchni stali: szybkość korozji stali zależy od stężenia elektrolitu, w którym się znajduje. Maksymalna szybkość korozji występuje przy 3-procentowym stężeniu roztworu $\mathrm{NaCl}$ [4].

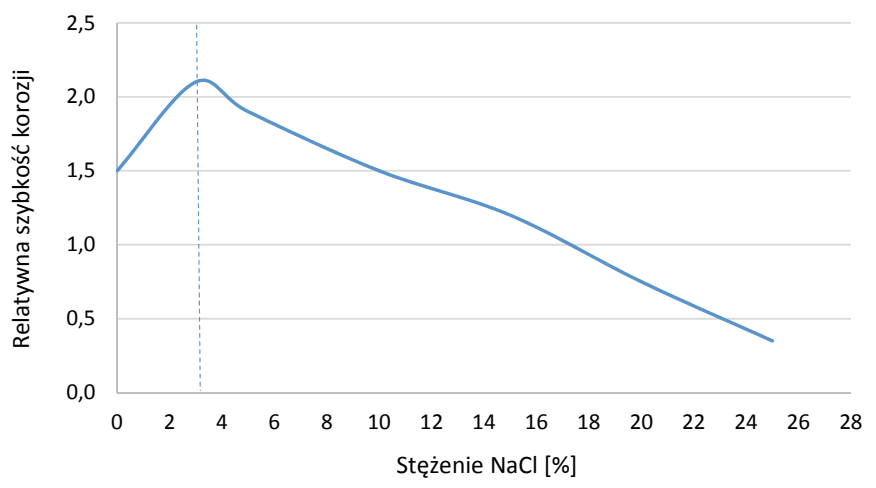

Rys. 3. Wpływ stężenia $\mathrm{NaCl}$ w elektrolicie na szybkość korozji

Przy stężeniu większym niż 3\% szybkość korozji maleje, gdyż następuje spadek rozpuszczalności tlenu w elektrolicie. Początkowo przy wzroście stężenia soli szybkość korozji gwałtownie rośnie, by osiągnąc maksimum przy stężeniu 3\%. Wynika to z faktu, że elektrolit, który powstaje na powierzchni stali, zawiera małe ilości składników jonowych, co sprzyja korozji.

- Kwasowość środowiska (pH): szybkość korozji zależy od stężenia jonów wodorowych w elektrolicie. Żelazo wypiera wodór z kwasów nieutleniających, zatem ze wzrostem ich stężenia (kwasowości) rośnie szybkość roztwarzania żelaza.

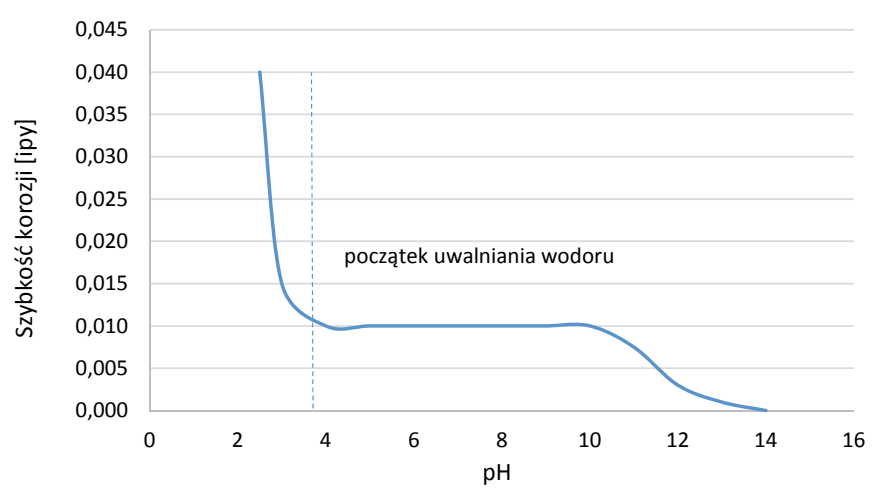

Rys. 4. Wpływ pH elektrolitu na szybkość korozji

Gdy pH ma wartość od 4 do 10, szybkość korozji spada i nie zależy od $\mathrm{pH}$. W tym obszarze powierzchnia stali pokrywa się produktami korozji (wytrąca się $\mathrm{Fe}(\mathrm{OH})$ ). Szybkość korozji jest określona przez szybkość dyfuzji tlenu przez warstwę wodorotlenku stykającą się ze stalą. Powyżej pH $=10$ szybkość korozji jeszcze bardziej spada, gdyż zaczyna się proces pasywacji stali [4].

- Temperatura: ze wzrostem temperatury zwiększa się szybkość reakcji, a tym samym korozji. Szybkość korozji zależy od tego, czy odbywa się w układzie zamkniętym, czy też otwartym.

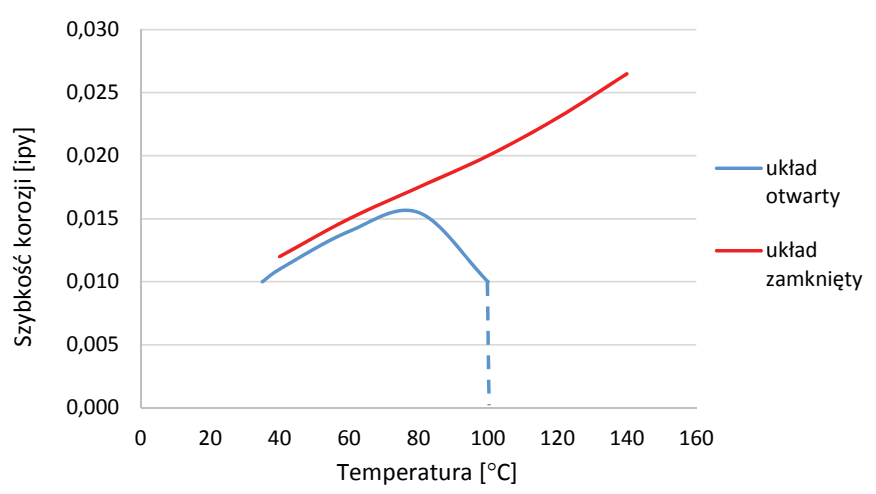

Rys. 5. Wpływ temperatury na szybkość korozji w układzie zamkniętym i otwartym

Temperatura powoduje wzrost szybkości reakcji, ale wraz ze wzrostem temperatury maleje rozpuszczalność tlenu w wodzie, co znacznie ogranicza szybkość korozji. 
W efekcie, przeprowadzając badania w układzie otwartym, umożliwiamy opuszczenie tlenu przez wodę i w pewnym momencie pojawi się maksimum korozji. W układzie zamkniętym szybkość korozji rośnie, gdyż podczas ogrzewania stężenie tlenu, którego ciśnienie w układzie wzrasta, jest ciągle duże i szybkość korozji staje się liniową funkcją temperatury [4].

- Rodzaj materiału: poszczególne rodzaje stali korodują z różną szybkością, w zależności od swojego składu, np. stale nierdzewne mają dodatki stopowe odpowiedzialne za zwiększenie ich odporności na korozję, a stale kwasoodporne posiadają dodatki stopowe podnoszące ich odporność na trawienie przez silne kwasy. Jednak do typowych zastosowań w transporcie metanu czy też ropy stale mają przede wszystkim dodatki zwiększające ich wytrzymałość na ciśnienie i polepszające trwałość.

\section{Kontrola parametrów polaryzacji i szybkość korozji na gazociągu}

O szybkości korozji metalu w elektrolicie decyduje kinetyka procesów elektrodowych: depolaryzacyjnych i polaryzacyjnych przebiegających podczas normalnej pracy ogniw korozyjnych, jak też wymuszonych przez celową polaryzację zewnętrzną (katodową) bądź też przez prądy błądzące. Miarą szybkości korozji w danym układzie metal-elektrolit jest wartość prądu płynącego przez granicę faz metal-elektrolit. Natomiast wartość potencjału elektrody określa stan termodynamiczny procesu elektrodowego (korozja, odporność, pasywacja). Przy braku oddziaływania prądu zewnętrznego potencjał konstrukcji jest tzw. potencjałem spoczynkowym. Metal chroniony katodowo przyjmuje potencjał polaryzacji bardziej ujemny od potencjału spoczynkowego, do którego dodaje się wartość napięcia będącego miarą polaryzacji aktywacyjnej i stężeniowej oraz omowej $\Delta U=I R$. Metal podlegający oddziaływaniu prądu błądzącego przyjmuje potencjał różny od potencjału spoczynkowego: bardziej dodatni, jeżeli prąd błądzący wypływa z metalu, względnie bardziej ujemny, jeżeli prąd błądzący wpływa do metalu.

Różnica potencjałów rurociąg-elektroda odniesienia stanowi potencjał elektrochemiczny rurociągu jedynie wówczas, gdy nie jest on poddany działaniu prądu zewnętrznego w miejscu wykonywania pomiaru. Natomiast w warunkach ochrony katodowej lub w warunkach przepływu prądu błądzącego przez granicę faz metal-elektrolit do wartości potencjału elektrochemicznego metalu dodaje się wartość spadku napięcia $\mathrm{w}$ elektrolicie $(\Delta \mathrm{U}=\mathrm{IR})$, czyli polaryzację omową.
Jeżeli celem pomiaru potencjału jest ocena skuteczności ochrony katodowej, to składowa IR powinna być wyeliminowana z mierzonej wartości potencjału. Jeżeli natomiast pomiary potencjałów wykonuje się w celu określenia stopnia zagrożenia korozyjnego, to dla ustalenia położenia stref anodowych i katodowych na konstrukcji poddanej oddziaływaniu prądu błądzącego - należy mierzyć wartości potencjałów zawierające składową IR. Jedną z metod eliminacji składowej omowej IR jest metoda pomiaru potencjału przy pomocy sondy symulującej [5].

Szybkość korozji można sprawdzić przy pomocy technik korozymetrycznych. W ochronie katodowej konstrukcji stalowych coraz bardziej popularny staje się pomiar szybkości korozji za pomocą korozymetrii rezystancyjnej. Zasada monitorowania skuteczności ochrony katodowej polega na ekspozycji w środowisku korozyjnym elektrody stalowej (czujnika korozymetrycznego) połączonej galwanicznie z konstrukcją, która jest chroniona katodowo. Czujnik korozymetryczny umieszcza się możliwie jak najbliżej chronionej katodowo konstrukcji. Po odpowiednim czasie kontroluje się ubytek masy danej próbki. W celu określenia ubytków korozyjnych ocenia się zmianę na podstawie wyznaczonych w czasie przyrostów rezystancji elektrycznej. Pomiary te można prowadzić dowolną liczbę razy, co zapewnia możliwość monitorowania korozji w sposób ciągły. W wyniku postępowania procesu korozji następuje stopniowe zmniejszanie przekroju próbki, natomiast jej długość nie ulega zmianie. Powoduje to wzrost rezystancji próbki w miarę upływu czasu ekspozycji w środowisku korozyjnym.

\section{Laboratoryjne badanie odspojenia powłoki izolacyjnej}

W Polsce w ostatnich latach stosowane są następujące powłoki izolacyjne gazociągów stalowych:

- powłoki 3LPE,

- powłoki 3LPP,

- powłoki termokurczliwe,

- powłoki nawojowe taśmowe,

- powłoki poliuretanowe PUR.
Badanie odspojenia katodowego powłoki w warunkach laboratoryjnych w przypadku powłok 3LPE i 3LPP przeprowadza się według normy PN-EN ISO 21809-1:2011. Dla powłok termokurczliwych i nawojowych w badaniach zjawiska odspojenia katodowego zastosowanie ma norma PN-EN 12068:2002, a dla powłoki PUR norma PN-EN 10290:2005. 
$\mathrm{W}$ wymienionych normach badanie odspojenia katodowego odbywa się w ten sam sposób, tą samą metodą badawczą i przy tym samym wyposażeniu. Jedyna różnica to inne stężenie roztworu $\mathrm{NaCl}$, które w przypadku badań powłok nawojowych i termokurczliwych [7] jest nieco mniejsze i wynosi $1,3 \%$, a w przypadku pozostałych powłok - $3 \%[9,10]$. Czas badania powłok wynosi $28 \mathrm{dni}$ w $23^{\circ} \mathrm{C}$ przy potencjale polaryzacji $1500 \pm 10 \mathrm{mV}$. Konstrukcja stanowiska badawczego do badań jest taka sama dla wszystkich rodzajów powłok, natomiast badania mogą być wykonane w dwóch wariantach. W pierwszym wariancie przygotowaną próbkę ze sztucznym defektem o średnicy $6 \mathrm{~mm}$ umieszcza się wewnątrz komory badawczej, gdzie za pomoca uszczelek i lewarka, którym dociska się powierzchnię próbki do komory badawczej, uszczelnia się miejsce styku próbki i komory badawczej $[7,9,10]$. Następnie po sprawdzeniu szczelności wodą destylowaną napełnia się naczynko roztworem chlorku sodu $(\mathrm{NaCl})$ odpowiednim do badanej powłoki. Później do naczynka nad sztuczny defekt wprowadza się elektrodę platynową, która spełnia rolę anody. Elektrodę kalomelową, która służy do kontroli potencjału w układzie, umieszcza się obok elektrody platynowej oraz w bezpośredniej bliskości sztucznego defektu. Układ polaryzujący jest zasilany przez potencjostat, którego biegun minusowy połączony jest z próbką, a biegun dodatni z elektrodą platynową. Potencjostat ma za zadanie stabilizację potencjału w układzie badawczym.

W drugim wariancie na próbkę stawia się naczynko badawcze, które uszczelnia się bezpośrednio na próbce $[7,9,10]$. Jednakże w wariancie pierwszym naczynko jest do wielokrotnego użytku, a w wariancie drugim najczęściej nie ma możliwości jego ponownego wykorzystania.

Przez cały czas badania należy kontrolować temperaturę próbki. Niekontrolowany wzrost temperatury albo jej wahania, np. dobowe, mogą przyczynić się do zwiększenia odspojenia powłoki. Po zakończeniu badania próbkę należy przepłukać pod bieżącą wodą i osuszyć. Następnie należy w miejscu defektu wykonać 6 nacięć co $60^{\circ}$ (dla powłok 3LPE i 3LPP liczba nacięć może wynosić od 6 do 12) i o długości co najmniej $30 \mathrm{~mm}$. Na fotografii 1 przedstawiono naciętą i oderwaną powłokę wokół defektu.

Powłokę podważa się ostrym końcem szpikulca, a nadmiar powłoki usuwa się, co ułatwia dokonanie pomiarów. Na fotografii 1 przedstawiono wielkość odspojenia katodowego powłoki 3LPE po 28 dniach polaryzacji w warunkach laboratoryjnych. Na zdjęciu widać odspojony obszar wokół centrum defektu. Centrum defektu pokryte jest kolorem jasnopomarańczowym. W okręgu czerwonym znajduje się eksponowana powierzchnia defektu wykonanego przed rozpoczęciem badania. Pomiędzy czerwonym i niebieskim okręgiem znajduje się obszar, gdzie powłoka 3LPE się odspoiła.

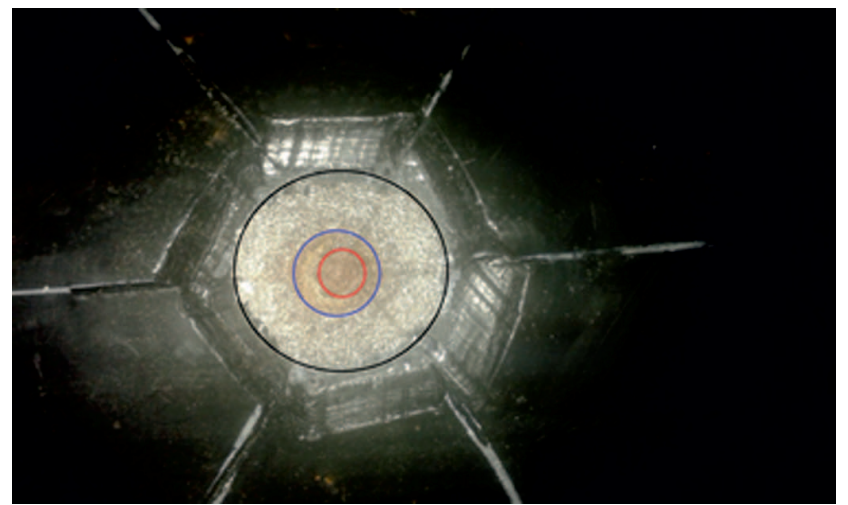

Fot. 1. Sztuczny defekt powłoki po badaniu wielkości odspojenia katodowego powłoki z wykonanymi nacięciami co $60^{\circ}$ i usuniętą powłoką

Jak widać, odspojenie powłoki wewnątrz defektu nie przebiegało równomiernie i z jednej strony wartość odspojenia jest większa. Pomiędzy zaznaczonym niebieskim i czarnym okręgiem znajduje się obszar bez usuniętej powłoki izolacyjnej dla lepszej analizy obszaru odspojenia powłoki. Poza czarnym okręgiem widoczne są promieniście rozchodzące się od środka defektu linie nacięcia powłoki.

$\mathrm{Na}$ fotografii 2 przedstawiono miejsce odspajania powłoki typu B30 w defekcie na próbce po 30 dniach badania. Wielkość odspojenia jest doskonale widoczna w postaci obszaru bez warstwy butylokauczukowej wokół centrum defektu (wewnątrz czerwonego okręgu).

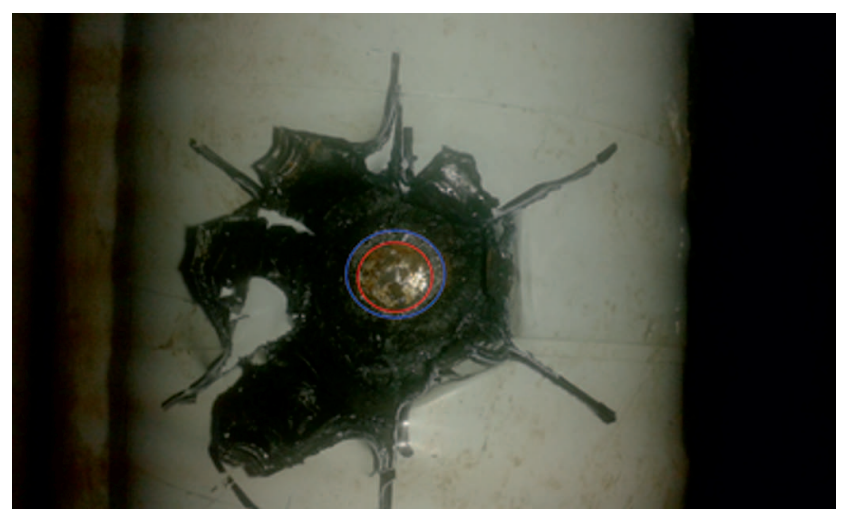

Fot. 2. Odspojenie powłoki wykonanej z taśm nawojowych wokół sztucznego defektu. Doskonale widoczny jest odspojony obszar wokół defektu powłoki

Pomiędzy czerwonym a niebieskim okręgiem znajduje się miejsce, gdzie powłoka odspoiła się od powierzchni stali. Poza okręgiem niebieskim znajduje się butylokauczuk, który nie uległ odspojeniu.

Wymagania maksymalnych dopuszczalnych wartości wielkości odspojenia katodowego powłoki dla poszczególnych rodzajów powłok według poszczególnych norm różnią się od siebie $[7,9,10]$. Dla powłok 3LPE i 3LPP wymagania są najostrzejsze i maksymalny dopuszczalny promień odspojenia 
wynosi $7 \mathrm{~mm}$, a dla powłok typu PUR: $8 \mathrm{~mm}$. W przypadku powłok termokurczliwych i wykonanych z taśm samoprzylepnych maksymalna dopuszczalna wielkość promienia odspojenia katodowego wynosi aż 20 mm. Oczywiście na wiel- kość odspojenia powłoki ma wpływ jakość powierzchni, na która powłoka jest nakładana. Standardem jest przygotowanie powierzchni zgodnie z normą PN-EN ISO 8501-1:2008 do stopnia Sa 2 1/2.

\section{Podsumowanie}

Zjawisko odspojenia katodowego powłoki jest powszechnie znane i stanowi duże zagrożenie dla gazociągu. Pozostawione bez kontroli może doprowadzić do awarii konstrukcji w miejscu powstania defektu powłoki izolacyjnej. Jednakże nie jest dostępna wiedza na temat, jaka szybkość odspojenia katodowego powłoki może wystapić w defekcie powłoki w rzeczywistych warunkach eksploatacyjnych konstrukcji.

Na szybkość odspojenia katodowego powłoki izolacyjnej może mieć wpływ pH roztworu, temperatura, natlenienie, rodzaj stali, z jakiej wykonany jest gazociąg, oraz przewodnictwo elektrolitu na powierzchni stali.

Ochrona katodowa stanowi czynne uzupełnienie niedoskonałości powłoki izolacyjnej. Zabezpiecza powierzchnię stali w miejscu powstania defektu powłoki, powodując obni- żenie szybkości korozji do wartości akceptowalnych. Jednak zbyt duża polaryzacja defektu może doprowadzić do zmian w elektrolicie w obrębie defektu i powstawania produktów korozji, a także nadmiernego wytwarzania pęcherzyków wodoru. Uwalniający się wodór z przestrzeni między powłoką a powierzchnią stali, na którą ta powłoka jest nałożona, może spowodować odspojenie powłoki. Długotrwały proces nadmiernej polaryzacji może doprowadzić do trwałego odspojenia powłoki nawet na znacznym obszarze. W odkrytej przestrzeni międzypowłokowej, która powstała w wyniku odspojenia powłoki, prąd ochrony katodowej ma utrudnione zadanie, aby dotrzeć do odsłoniętych stalowych powierzchni. Może to spowodować zwiększenie szybkości korozji, a w efekcie możliwość wystąpienia perforacji ścianki gazociągu.

Prosimy cytować jako: Nafta-Gaz 2017, nr 6, s. 405-410, DOI: 10.18668/NG.2017.06.05

Artykuł nadesłano do Redakcji 19.12.2016 r. Zatwierdzono do druku 14.03.2017 r.

Artykuł powstał na podstawie pracy statutowej pt. Analiza zjawiska odspajania katodowego powłoki na podstawie badań terenowych oraz badań laboratoryjnych - praca INiG - PIB na zlecenie MNiSW; nr zlecenia: 0089/GP/16/01, nr archiwalny: DK-4100-0080/16.

\section{Literatura}

[1] Baeckmann W., Schwenk W., Prinz W. (eds.): Handbook of Cathodic Corrosion Protection. Theory and Practice of Electrochemical Protection Processes. Third Edition, 1997.

[2] Dietrich A.: Ocena ryzyka w transporcie gazu rurociagami. Nafta-Gaz 2009, nr 3, s. 248-254.

[3] Dietrich A., Badowski J.: System komputerowy oceny stanu technicznego i analizy ryzyka dla dystrybucyjnych sieci gazowych. Nafta-Gaz 2009, nr 11, s. 895-900.

[4] Jones F.N., Wicks Z.W., Papas S.P., Wicks D.A.: Organic Coatings: Science and Technology. 3rd edition, 2007.

[5] Martinez S., Zulj L.V., Kapor F.: Disbonding of underwatercured epoxy coating caused by cathodic protection current. Corrosion Science 2009, vol. 51, no. 10, s. 2253-2258.

[6] Ostaszewicz J.: Ochrona elektrochemiczna przed korozja. Wydawnictwa Naukowo-Techniczne, Warszawa 1991.

\section{Akty prawne i normatywne}

[7] PN-EN 10290:2005 Rury stalowe i łaczniki na rurociagi przybrzeżne i morskie - Powłoki zewnętrzne z poliuretanu lub poliuretanu modyfikowanego nanoszone w stanie ciektym.

[8] PN-EN 12068:2002 Ochrona katodowa - Zewnętrzne powłoki organiczne stosowane łacznie z ochrona katodowa do ochrony przed korozja podziemnych lub podwodnych rurociągów stalowych - Taśmy i materiały kurczliwe.
[9] PN-EN 12954:2004 Ochrona katodowa konstrukcji metalowych $w$ gruntach lub $w$ wodach - Zasady ogólne i zastosowania dotyczace rurociagów.

[10] PN-EN ISO 21809-1:2011 Powłoki zewnętrzne rurociagów podziemnych i podmorskich stosowanych $w$ rurociagowych systemach transportowych - Część 1: Powtoki poliolefinowe (3-warstwowe PE i 3-warstwowe PP).

[11] PN-EN ISO 8501-1:2008 - Przygotowanie podtoży stalowych przed naktadaniem farb i podobnych produktów - Wzrokowa ocena czystości powierzchni-Czesść 1: Stopnie skorodowania i stopnie przygotowania niepokrytych podtoży stalowych oraz podtoży stalowych po całkowitym usunięciu wcześniej nałożonych powłok.

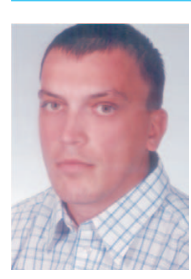

Mgr inż. Paweł STOCHAJ

Główny specjalista inżynieryjno-techniczny; kierownik Laboratorium Eksploatacji Gazociągów Instytut Nafty i Gazu - Państwowy Instytut Badawczy ul. Lubicz 25 A 31-503 Kraków E-mail:pawel.stochaj@inig.pl 